九州大学学術情報リポジトリ

Kyushu University Institutional Repository

\title{
EROTYLIDAE FROM NEW GUINEA AND HER ADJACENT ISLANDS II (COLEOPTERA)
}

Chujo, Michitaka

Chujo, Michio

https://doi.org/10.5109/2504

出版情報：ESAKIA. 26，pp. 25-37，1988-01-25. 九州大学農学部附属彦山生物学実験所 バージョン：

権利関係 : 


\title{
EROTYLIDAE FROM NEW GUINEA AND HER ADJACENT ISLANDS II (COLEOPTERA) $^{1,2)}$
}

\author{
M ichitaka ChÛjô \\ Hikosan Biological Laboratory, Faculty of Agriculture, \\ Kyushu University, Hikosan, Fukuoka 824-07 \\ and \\ M ICHIO CHÛJô ${ }^{3)}$ \\ Kamata 1-6-16-505, Ohta-ku, Tokyo 144
}

\begin{abstract}
New taxa (6 new species and 3 new subspecies of Episcaphula) described in this paper are as follows :

Episcaphula (Episcaphula) separata sp. nov.

E. (E.) separata wamenae subsp. nov.

$E$. (E.) latifasciata sp. nov.

E. (E.) coerulea sp. nov.

E. (E.) variabilis sp. nov.

E. (E.) lanceolata sp. nov.

E. (Tropidoscaphula) sedlaceki sp. nov.

$E$. (T.) sedlaceki mayolana subsp. nov.

$E$. (T.) sedlaceki nigripes subsp. nov.

E. (T.) quadrisignata Crotch, 1876 is recorded from New Guinea for the first time.
\end{abstract}

This is the second report of our study on the family Erotylidae of New Guinea and her adjacent islands. The materials on which our study was based belong to the B. P. Bishop Museum except for only one specimen which was collected by the senior author in 1984. Five new species and one new subspecies of the subgenus Episcaphula, and one new species and two new subspecies of the subgenus Tropidoscaphula are described. And also E. (T.) quadrisignata Crotch, 1876 is newly recorded from mainland of Papua New Guinea. About ten more species belonging to this genus will be treated in a next paper.

1) Contribution from the Hikosan Biological Laboratory, Faculty of Agriculture, Kyushu University, Hikosan (Ser. 3, No. 8).

2) Partial result of the study supported by Grant-in-Aid for Overseas Scientific Survey from the Japanese Ministry of Education, Science and Culture, No. 59041048 to Kyushu University (Prof. Y. Hirashima).

3) Professor Emeritus, Kagawa University. 


\section{Acknowledgement}

We are grateful to Dr. G. Allan Samuelson of B. P. Bishop Museum, Honolulu, Hawaii for the loan of the valuable specimens. Without whose cooperation this paper could not be made. We are also respectful to the late Dr. \& Mrs. J. Linsley Gressitt for his contribution to entomology and zoogeography of New Guinea.

We wish to express our appreciation to Prof. Y. Hirashima, the head of the Hikosan Biological Laboratory, Kyushu University for his support to the present study. The senior author is also much indebted to Prof. Y. Hirashima for the privilege of participation to the 1984 Expedition to Papua New Guinea.

\section{Subfamily DACNINAE}

Tribe DaCNinI

\section{Genus E piscaphula Crotch}

\section{Subgenus Episcaphula Crotch}

Episcaphula : Heller, 1918 (1920), Arch. f. Naturg., 84, A(8) : 56.

\section{Episcaphula (Episcaphula) separata sp. nov.}

Obovate, blackish brown to black, antennae and legs dark brown, two markings on both sides of pronotum and four elytral markings dark red.

Head weakly convex, clypeus trapezoidal, roundly bent down anteriorly, lateral border feebly convex, front border nearly straight, very densely punctate, the punctures becoming sparser from
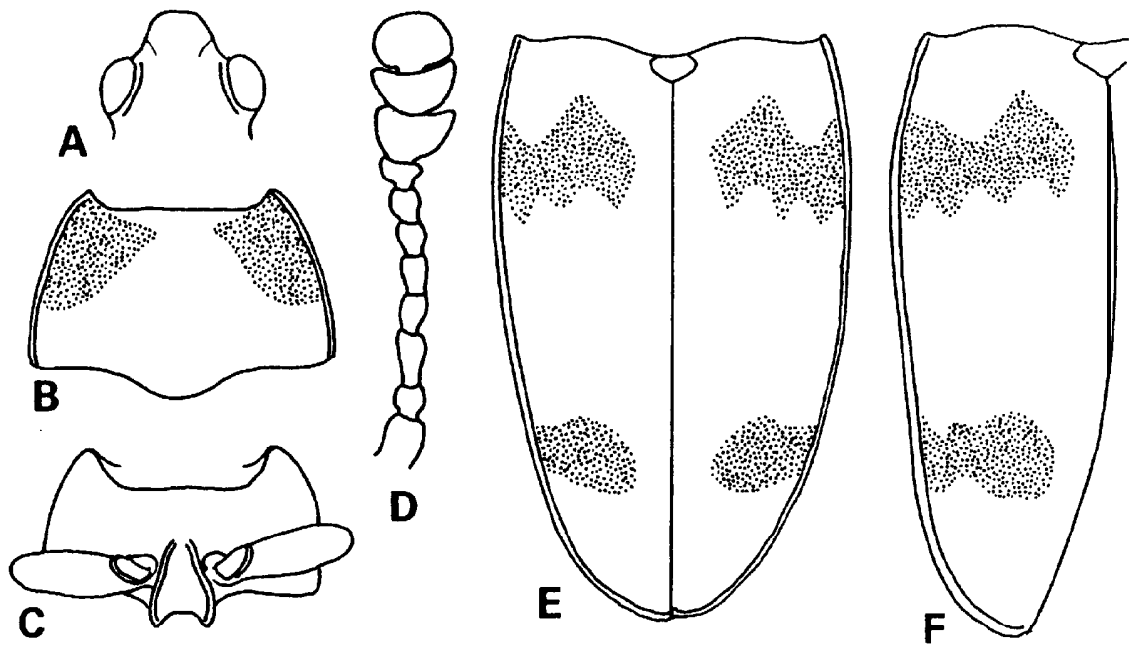

Fig. 1. Episcaphula (Episcaphula) separata sp. nov. A : Dorsal view of head. B : Dorsal view of pronotum. C: Ventral view of prosternum. D : Dorsal view of left antenna. E: Dorsal view of elytra. F: Dorso-lateral view of left elytron. 
clypeus to vertex ; eye strongly and roundly punctate. Antenna rather slender and long, relative length of each segment (base to apex) $4.0: 2.0: 4.0: 2.5: 2.5: 2.5: 2.0: 2.0: 4.0: 4.0: 5.0$; club segments comparatively large, $6 / 13$ times as wide as long.

Pronotum transverse, trapezoidal, about 0.58 times as long as wide ; basal border with middle part roundly expanded, hind corner rounded ; lateral border slightly arcuate, comparatively strongly converging forwards, very finely marginate, with a large puncture near both extremities ; front comer triangularly produced forwards, apex rather dully angulate; surface with very sparse and large punctures among dense and small punctures, pronotal dark red markings covered both sides of front half as shown in Fig. 1B. Prostemum with median part convex, densely pubescent-punctate, intercoxal area widened posteriorly, lateral border nearly straight, hind border shallowly, triangularly sinuate, with procoxal lines comparatively long, anterior end of the lines feebly bent inwards. Scutellum transverse, obpentagonal, every side and corner weakly rounded.

Elytra gently convex, widening from base to about $1 / 4$, and then gradually narrowing towards rounded apex, 1.6 times as long as wide, lateral border narrowly marginate ; with vestigial files of punctures, interstices very finely and densely punctate, with basal transversal fascia at widest part, interior side of the fascia not reaching suture and exterior side reaching just inside of marginal area, basal side shallowly sinuate, apical side with four short dental projections, with the other transversal fascia at $3 / 4$ from base of elytron, interior side not reaching suture, exterior side just reaching marginal area.

Mesosternum rather transverse, with ( )-shaped fine grooves of which slightly converged anteriorly. Metasternum comparatively strongly convex, finely and densely punctate, every puncture with rather long, fine and yellow pubescence, punctures on metepisterna and metepimeron as same as metastemal ones in size and density, with median line very fine and rather vestigial at basal half ; mesocoxal lines absent, with metacoxal lines fine and long. Every abdominal stemite densely pubescent-punctate,

Length : 6.7-7.7 mm. Width : 2.9-3.4 mm.
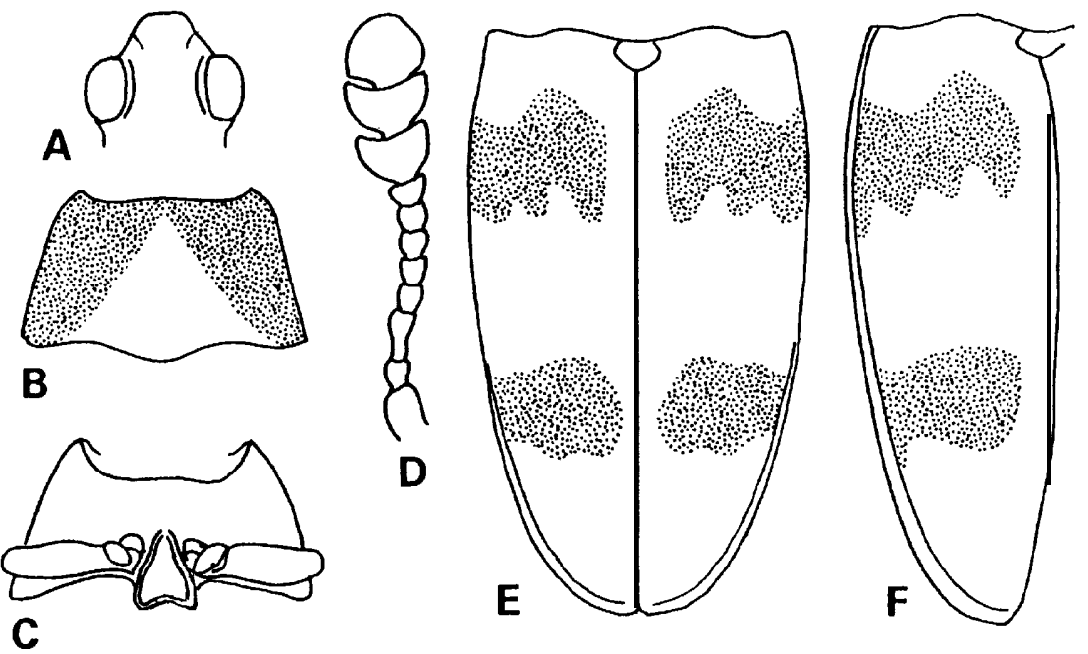

Fig. 2. Episcaphula (Episcaphula) separata wamenae subsp. nov. A : Dorsal view of head. B : Dorsal view of pronotum. C : Ventral view of prosternum. D : Dorsal view of right antenna. E : Dorsal view of elytra. F: Dorso-lateral view of left elytron. 
Type material : Holotype ơ (preserved in B. P. Bishop Mus.), Wau (1,200 m), Morobe Distr., P. N. G. (NE), 16. i. 1963, J. Sedlacek. Paratypes : 499, Wau (1,200 m), Morobe Distr., P. N. G. (NE), 1-4. x. 1962, J. Sedlacek ; , Wau (1,200-1,250 m), Morobe Distr., P. N. G. (NE), 13. viii. 1964, J. Sedlacek.

GEN. distr. : Papua New Guinea (Morobe Distr.).

This species is related to E.(E.) xanthosticta Crotch, 1876 from Waigeo I., but is easily distinguished from the latter by the following characters: Antennae rather reddish brown, pronotum with sparse and large punctures among dense and small punctures, antero-lateral part of the surface dark red, elytral subbasal fascia rather narrow, dentate at apical side of it, exterior side of post median one reaching marginal area.

\section{Episcaphula (Episcaphula) separata wamenae subsp. nov.}

This new subspecies is separated from the nominate subspecies of E.(E.) separata sp. nov. by the following characters : Both sides of pronotum nearly straightly converging forwards and roundly narrowed at apical $1 / 5$, pronotal obtriangular markings enlarged as shown in Fig. 2B, every elytral fascia much thicker.

Length : 6.9-8.4 mm. Width : 3.0-3.6 mm.

Type material : Holotype ơ (preserved in B. P. Bishop Mus.), Wamena (1,700 m), N. G. (NETH), 10-25. ii. 1960, T. C. Maa. Paratopotypes : 499, same collecting data as holotype.

Gen. DISTR.: West New Guinea.

\section{Episcaphula (Episcaphula) latifasciata sp. nov .}

Elliptic, moderately convex, wholly shining black, elytral four fasciae dark orange.

Head comparatively small, rather strongly and densely punctate, weakly convex, trapezoidal, roundly bent down forwards, clypeal suture vestigial ; submentum nearly flat, strongly and very sparsely punctate ; gula roundly convex, very smooth. Eye rather small, finely facetted, with inner
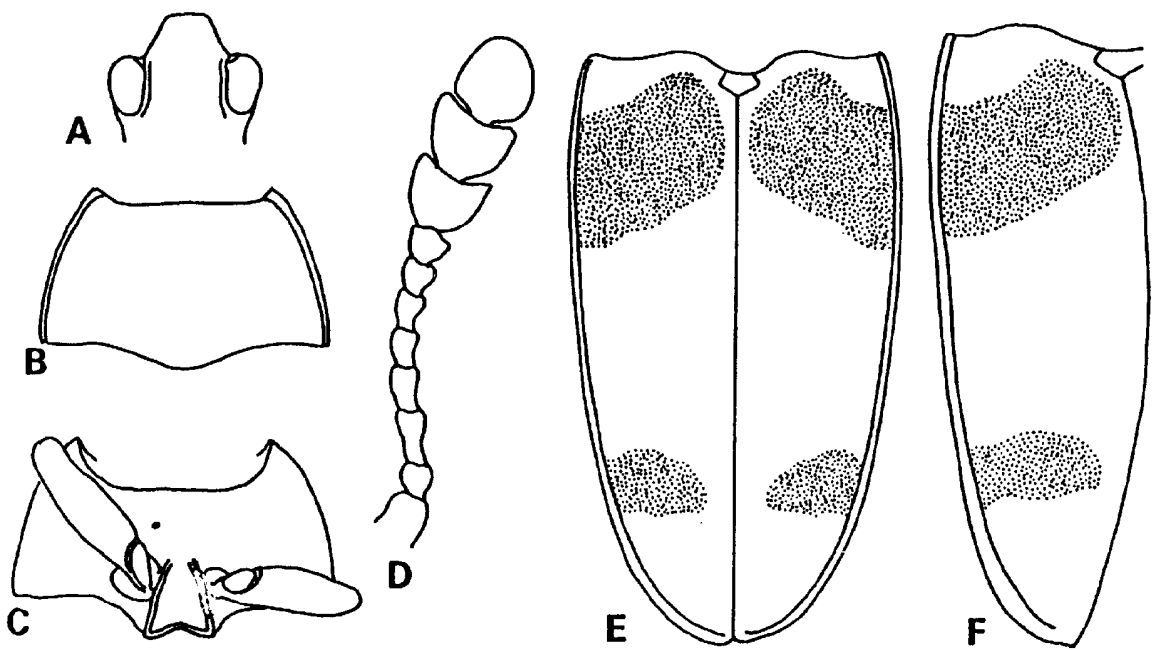

Fig. 3. Episcaphula (Episcaphula) latifasciata sp. nov. A : Dorsal view of head. B : Dorsal view of pronotum. C: Ventral view of prosternum. D: Dorsal view of left antenna. E: Dorsal view of elytra. F: Dorso-lateral view of left elytron. 
ocular groove fine and long. Antenna rather slender, 3rd segment about 2.5 times as long as wide, antennal club 2.5 times as long as wide, rather loosely joined each other ; relative length of each segment (base to apex) $4.0: 2.0: 3.8: 2.5: 2.5: 2.5: 2.0: 2.0: 4.0: 4.0: 5.0$.

Pronotum transverse, trapezoidal, rather strongly converging forwards ; basal border finely marginate, slightly rounded, with a large and deep puncture near both extremities ; front comer triangularly produced forwards, apex pointed ; front border widely and somewhat shallowly sinuate. Prosternum convex at median part, very strongly, densely pubescent-punctate except for median and subapical parts, median part very sparsely pubescent-punctate ; prosternal process nearly smooth, roundly convex at intercoxal area, sparsely and very finely pubescent, apical border widely, triangularly sinuate, procoxal lines nearly straightly converged anteriorly, the lines shortly bent inwards at apical ends, but not joined each other. Scutellum somewhat semicircular, surface nearly smooth.

Elytral length $3 / 4$ times as long as whole length, widest at $1 / 5$ from base, gently narrowing towards apex from there, lateral border comparatively narrowly marginate, the margin gradually widening anteriorly ; dorsum strongly convex, with very fine files of punctures, interstices very finely, densely pubescent-aciculate; subbasal fascia with exterior side reaching just inside of lateral margin; with subapical fascia transversely ovate, covering from 1st interstices to just inside of lateral margin, basal side strongly and apical side weakly rounded.

Mesosternum subpentagonal at intercoxal area, weakly convex, with ( )-shaped grooves of which weakly converged anteriorly, mesepisternum smooth, mesepimeron very sparsely pubescentaciculate. Metastemum strongly convex, rather sparsely pubescent-punctate, median line recognized at basal half, metepisternum densely pubescent-punctate, metepimeron nearly smooth, metacoxal lines comparatively long. Abdominal sternites densely pubescent-punctate.

Length : 8.4-9.6 mm. Width : 3.5-4.3 mm.

Type Material: $\sigma^{\top}$ (preserved in B. P. Bishop Mus.), Wamena (1,700 m), N. G (NETH), 10-25. ii. 1960, T. C. Maa. Paratopotypes : ̛ \& $\&$, same collecting data as holotype. Paratype : $\sigma^{7}, 20 \mathrm{~km} \mathrm{SW}$. Kainantu (1,800 m), East Highlands, P. N. G. (NE), 16. i. 1966, J. Sedlacek.

Gen DISTR. : New Guinea Proper.

This species is closely related to E.(E.) separata sp. nov., but is clearly distinguished from the latter by the following characters: Body much larger, wholly blackish, pronotum and prosternum evenly black, pronotum without marking ; relative length of each antennal segment different, relative length of elytra to whole body length much longer ; prosternum very strongly punctate, ( )-shaped grooves on mesosternum much longer and more strongly warped ; subbasal fascia on elytron weakly slanted, without dental projection at apical side of the fascia ; all legs evenly black.

\section{Episcaphula (Episcaphula) coerulea sp. nov.}

Elliptic, strongly convex, dorsum black with metallic blue tinge, antennae black, elytral markings pale yellow to dark yellow, whole undersurface, mouth parts and legs blackish brown, pilosities on underside of every tarsus yellowish brown.

Head trapezoidal, gently convex, sparsely and shallowly punctate, dorsal part of antennal socket moderately convex ; oblique part of clypeal suture visible, vertical part of it invisible ; clypeus trapezoidal, gently bent down anteriorly, lateral side nearly straight, front corner rounded, front border roundly sinuate at middle part in $\sigma^{\prime}$, very feebly and wholly sinuate in $q$, rather densely aciculate. Antenna robust, 3rd segment 2.2 times as long as wide, 4th to 7 th ones nearly moniliformed and nearly same in size and figure each other, 4th 1.25 times as long as wide, 8th one gently dilated towards apex, club segments twice as long as wide, relative length of each segment (base to apex) $4.0: 2.0: 3.8: 2.5: 2.5: 2.5: 2.5: 2.5: 5.0: 5.0: 5.0$. Eye moderately expanded outwards, rather finely 

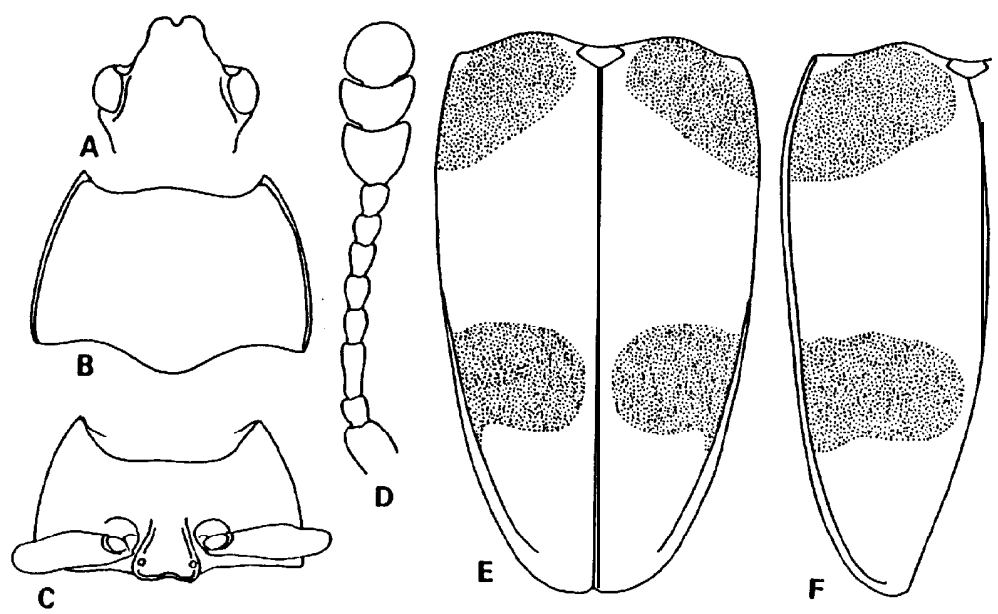

Fig. 4. Episcaphula (Episcaphula)coerulea sp. nov. A : Dorsal view of head. B : Dorsal view of pronotum. C : Ventral view of prosternum. D: Dorsal view of left antenna. E: Dorsal view of elytra. F: Dorso-lateral view of left elytron.

facetted, with inner ocular groove fine and long. Submentum very shallowly depressed at middle part, sparsely pubescent-aciculate; gula with front border strongly marginate and depressed, front half part sparsely and very strongly pubescent-punctate.

Pronotum transverse (5:8), moderately convex, sparsely pubescent-aciculate, with subbasal foveae small and very shallow ; basal border bisinuate, hind corner rounded ; lateral border arcuate outwards, gently converging forwards, very narrowly marginate, with a large and deep puncture near both extremities; front corner rather triangularly produced forwards, apex pointed, front border sinuate in --shaped. Prosternum roundly convex, front submarginal area with longitudinal wrinkles, middle part with several thick, transversal wrinkles, prosternal process strongly widening apically, gently convex, sparsely pubescent-aciculate, with procoxal lines interrupted by large and deep puncture near apical corner. Scutellum transverse, obpentagonal, about 2.5 times as wide as long, very feebly and sparsely pubescent-aciculate.

Elytra widest at $1 / 5$ from base, and then very weakly narrowing anteriorly, apex widely rounded ; dorsum very strongly convex, feebly and sparsely aciculate, irregularly, finely and densely wrinkled, 7 to 8 files of punctures hardly recognized only in elytral fasciae, each elytron with two fasciae, one at basal and the other at post middle part, the former thick and oblique, a part of its basal side reaching basal border of elytron, its interior side not reaching suture and exterior side reaching just inside of lateral marginal area, more closely approaching suture than the former one ; lateral border somewhat widely marginate and reflexed at basal 4/5, and then the marginal recurvature gradually faded-out towardsapex of elytron.

Mesosternum rather strongly convex, sparsely aciculate and irregularly wrinkled ; mesepisternum and mesepimeron nearly flat, very feebly aciculate. Metasternum strongly convex, very sparsely aciculate, anterior border widely marginate, submarginal area of it shallowly depressed ; metepisternum very minutely and sparsely aciculate, metepimeron nearly smooth. Abdominal sternites weakly punctate, the punctures gradually becoming larger and denser from base to apex. Every tibia rather slender.

Length : 8.0-10.1 mm. Width : 3.6-4.4 mm.

Type Material : Holotype ơ (preserved in B. P. Bishop Mus.), Aseki (1,800 m), Morobe Distr., P. 
N. G. (NE), 30. iv. 1974, Reni \& Petrus. Paratopotype : $q$, same collecting data as holotype.

Gen. distr. : Papua New Guinea.

This species is closely allied to E.(E.) latifasciata sp. nov., but is separated from the latter by the following characters : Head and pronotum weakly and sparsely aciculate, without large punctures among them, relative length of each antennal segment different, pronotum more strongly convex, elytron without visible file of punctures, a part of basal fascia of elytron reaching basal border of elytron, post median one nearly of the same thickness as basal one, prosternum weakly and sparsely punctate, prosternal process not trapezoidal.

\section{Episcaphula (Episcaphula) variabilis sp. nov.}

Obovate, blackish brown to black, mouth parts, antennae and all legs dark brown, pronotal markings and elytral fasciae yellowish orange.

Head elongate trapezoidal, gently convex, weakly and roundly bending down apically, lateral border weakly and roundly expanded on antennal socket, front border triangularly notched at middle part in $\stackrel{\circ}{\circ}$, but nearly straight in $\mathcal{Q}$, clypeus with fine and dense punctures and the punctures becoming sparser towards vertex, with inner ocular groove short. Antenna somewhat robust, relative length of each segment (base to apex) $3.5: 2.0: 4.8: 3.5: 3.0: 3.0: 3.0: 3.0: 4.0: 4.0: 3.0$, each of 5 th to 7 th segments nearly equal in shape each other, each one 1.5 times as long as wide, 8th one triangularly dilate towards apex (length : width $=3.0: 2.6$ ), club segments tightly joined each other.

Pronotum nearly transverse, about $7 / 10$ times as long as wide, comparatively strongly convex ; sparsely punctate, with a pair of yellowish red obtriangular markings a little behind front border ; basal border shallowly bisinuate, basal corner narrowly rounded ; lateral border weakly arcuate and narrowly marginate, with a large and deep puncture near both extremities ; apical comer acutely projected forwards; front border shallowly and roundly sinuate. Prosternum roundly convex at median part, sparsely pubescent-punctate ; intercoxal area comparatively wide, prosternal process dilate towards apex, lateral border roundly expanded, shallowly depressed in median part, with a pair of large punctures just inside of procoxal lines, the lines rather short and shallow. Scutellum transversely pentagonal, each side and corner weakly rounded, very sparsely aciculate.

Elytra comparatively strongly convex, 1.7 times as wide as long, weakly widened towards $1 / 4$ from base, and then straightly tapered anteriorly, apical part of elytra narrowly rounded, lateral border somewhat widely marginate and reflexed; with very weak files of punctures, elytron with two narrow yellowish orange fasciae, subbasal one rather waved, somewhat divided in two markings, the other one at about $5 / 8$ from base, roundly bent basally, both fasciae run from the 2 nd files of punctures to just inside of lateral margin. Mesosternum somewhat transversely pentagonal, roundly convex, anterior half of median part depressed longitudinally, inside of lateral border obliquely and shallowly depressed, mesocoxal lines absent ; metasternum roundly convex, sparsely pubescent-punctate, with very fine median line at basal $4 / 5$, metacoxal lines absent. Every femur yellowish brown, with both ends dark brown, every tibia brown at basal half, apical half paler.

Length : 8.2-9.7 mm. Width : 3.3-3.5 mm.

Type material : Holotype : ơ (preserved in B. P. Bishop Mus.), Kiunga (35 m), Fly River, P. N.

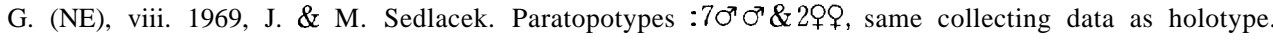
Paratypes :3ơ ơ \& 299, Olsobip (400-600 m), Fly River, P. N. G. (NE), viii. 1969, J. \& M. Sedlacek.

Gen. Distr.: Papua New Guinea.

This species is related to E.(E.) novaeguineae Heller, 1920 from Papua New Guinea, but is easily distinguished from the latter by the following characters : Antenna with 3rd segment 1.4 times as long as 4th one, pronotum $7 / 10$ times as long as wide, with two markings by front border, posterior fascia 

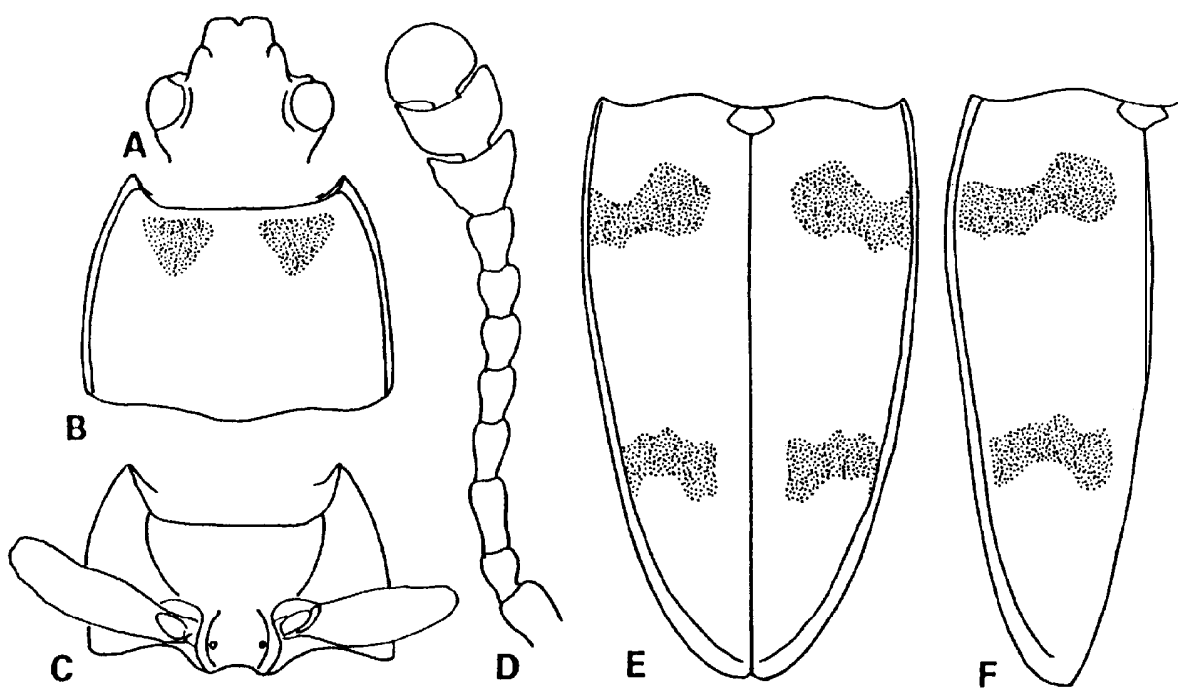

Fig. 5. Episcaphula (Episcaphula) variabilis sp. nov. A : Dorsal view of head. B : Dorsal view of pronotum. C : Ventral view of prostemum. D: Dorsal view of left antenna. E : Dorsal view of elytra. F : Dorso-lateral view of left elytron.

of elytron sometimes divided in two markings, every femur with both ends dark brown, and every tibia with basal half dark colored.

\section{Episcaphula (Episcaphula) lanceolata sp. nov.}

Elliptic, with both ends attenuate, somewhat black, with pronotal markings and elytral fasciae dark red, femora brown to dark brown except for blackish brown both ends, every tibia blackish brown, tarsal pilosities stained yellow.

Head weakly convex, sparsely punctate, oblique part of clypeal suture visible and shallowly depressed, clypeus trapezoidal, densely punctate, roundly bent downwards at apex, lateral border nearly straight, apical border shallowly and triangularly sinuate in $\mathcal{O}^{\prime}$, nearly straight in $q$, submentum transverse, shallowly depressed, nearly smooth, only front submarginal area punctate ; gula roundly convex, surface nearly smooth. Antenna comparatively short, rather robust, relative length of each segment (base to apex) $3.0: 2.0: 3.0: 2.5: 2.0: 2.0: 2.0: 2.0: 4.0: 4.0: 4.0$, 3rd one 2.5 times as long as wide, 4th one 1.25 times as long as wide, club segments 2.5 times as long as wide, tightly joined each other. Eye rather finely facetted, with inner ocular groove very long.

Pronotum transverse, trapezoidal, basal border shallowly bisinuate, hind corner obtusely angulate ; lateral border weakly warped outwards in $\mathcal{O}^{7}$, nearly straight in $\$$, very narrowly marginate, with a large and deep puncture near both extremities ; front corner triangularly produced forwards ; front border comparatively shallowly sinuate; dorsum rather strongly convex, very sparsely aciculate, with a pair of obtriangular dark red markings near front corner, but the markings sometimes vestigial or lacking. Prosternum roundly convex, sparsely and minutely punctate ; prosternal process very sparsely punctate, comparatively wide, strongly dilate posteriorly, both sides warped and slightly reflexed, apical border very finely marginate, shallowly and triangularly sinuate ; procoxal lines short and very shallow, sometimes vestigial. Scutellum rather pentagonal, sparsely 
aciculate.

Elytra widest at about $1 / 6$ from base, following $5 / 6$ gradually narrowing apically, apex narrowly rounded, lateral border comparatively widely marginate and reflexed ; dorsum rather strongly convex, sparsely aciculate, with very fine 7 files of punctures recognized only in elytral fascia, each elytron with two dark red fasciae, subbasal one at just before widest part, rather widely, deeply and triangularly sinuate at middle of basal side, widely and very shallowly sinuate at apical side, and its both sides reaching neither 1 st file of punctures nor lateral margin, the other one at about $3 / 5$ from base, a little narrower than the former, slightly arcuate basally.

Mesostemum transverse, weakly convex, feebly and very sparsely pubescent-aciculate, very finely and longitudinally wrinkled, lateral border nearly straight and weakly narrowing anteriorly ; mesepistemum and metepimeron very weakly depressed ; mesocoxal lines absent. Metasternum strongly convex, rather sparsely pubescent-aciculate, apical border thickly marginate, especially very thick at inter mesocoxal area, metepisternum comparatively densely pubescent-aciculate, metepimeron nearly smooth, metacoxal lines absent.

Abdominal sternites gently convex, each of 1 st to 3 rd sternites densely pubescent-punctate at basal half and nearly smooth at apical half, terminal sternite wholly, densely pubescent-punctate, with submarginal area weakly depressed. Every femur rather robust. Each of penultimate segment of tarsi with a pair of long hairs transversally on underside, terminal segment with longitudinal two rows of sparse hairs on underside.

Length : 7.4-9.8 mm. Width :3.0-4.1 mm.

Type material : Holotype ơ (preserved in B. P. Bishop Mus.), Garaina-Saureli (900-1,400 m), P. N. G. (NE), 5. i. 1968, J. \& M. Sedlacek. Paratopotypes: $\sigma^{7} \&$ $\&$, same collecting data as holotype. Paratypes : $\uparrow$, Wau (1,050 m), Morobe Distr., P. N. G. (NE), 4. xi. 1961, J. \& M. Sedlacek ; + , Wau (1,250-1,300 m), Morobe Distr., P. N. G. (NE), 11. x. 1962, J. Sedlacek ; , Wau (1,250-1,300 m), Morobe Distr., P. N. G. (NE), 11. x. 1962, J. Sedlacek ; 9 (light trap), Wau (1,200 m), Morobe Distr., P. N. G.
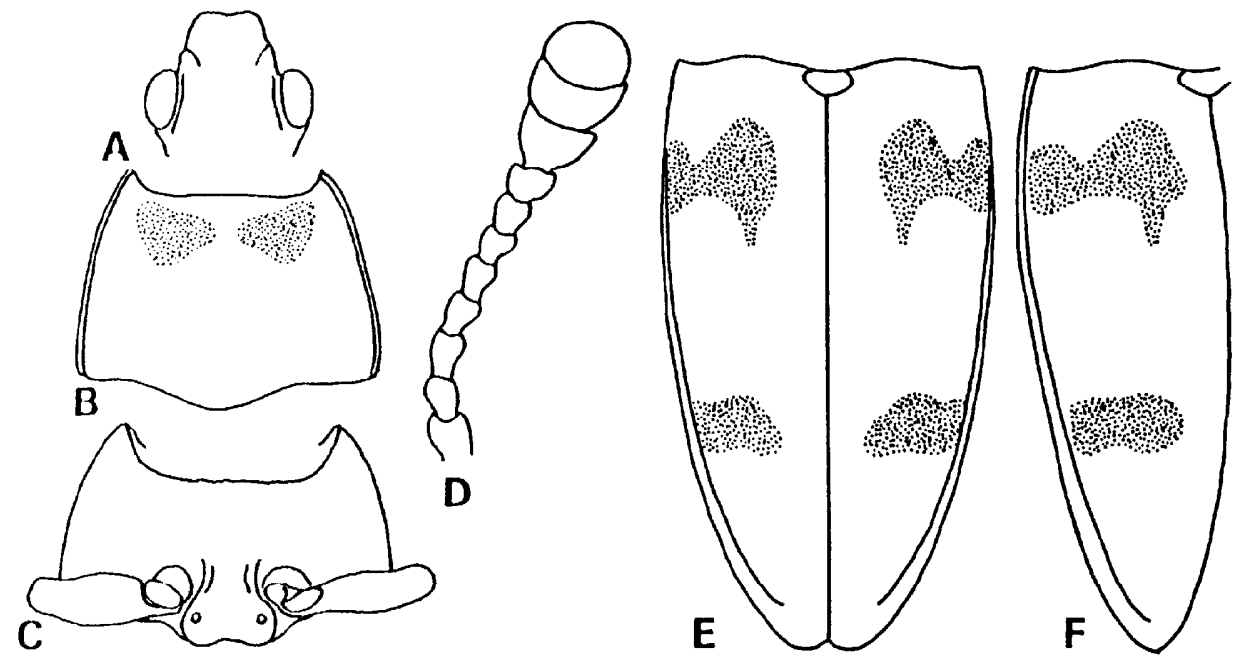

Fig. 6. Episcaphula(Episcaphula) Zanceolata sp. nov. A : Dorsal view of head. B : Dorsal view of pronotum. C : Ventral view of prosternum. D : Dorsal view of left antenna. E :Dosal view of elytra. F : Dorso-lateral view of left elytron. 
(NE), 25. iii. 1966, J. L. Gressitt \& Wilkes; \&, Garaina (800 m), P. N. G. (NE), 4. i. 1968, J. \& M. Sedlacek.

GEN. DISTR. : Papua New Guinea.

This species is closely related to E.(E.)variabilis sp. nov., but is distinguished from the latter by the following characters : Head more sparsely and weakly punctate, clypeal front border shallowly and widely sinuate, eye gently expanded outwards ; pronotum more strongly converging forwards, with lateral border more weakly warped outwards ; pronotum and elytra very feebly aciculate ; mesoand metasternum and abdominal sternites more densely punctate.

\section{Subgenus Tropidoscaphula Heller}

Tropidoscaphula Heller, 1918 (1920), Arch. f. Naturg., 84, A(8) : 56 (key) [Type species :E. (E.) corallipes Gorham from Amboina I.].

\section{Episcaphula (Tropidoscaphula) sedlaceki sp. nov.}

Elliptic, blackish brown to black, pronotal markings and subapical markings of elytra yellowish red, elytral fasciae yellowish orange, all femora stained yellow except for dark brownish both ends, all tibiae reddish brown.

Head very feebly convex, gently bent down forwards, elongate trapezoidal, lateral border nearly straight, front corner rounded ; sparsely aciculate, clypeal suture invisible ; submentum nearly flat, very strongly and very sparsely punctate; gula roundly convex at median part, mostly smooth, with front marginal area strongly punctate; gena strongly punctate. Eye rather finely facetted, with inner ocular groove narrow and shallow. Antenna rather slender, relative length of each segment (base to apex) $4.0: 2.0: 4.5: 3.0: 3.0: 2.5: 2.0: 2.0: 4.0: 4.5: 4.5$, 3rd one 2.25 times as long as wide, club segments 2.1 times as long as wide, tightly joined each other.
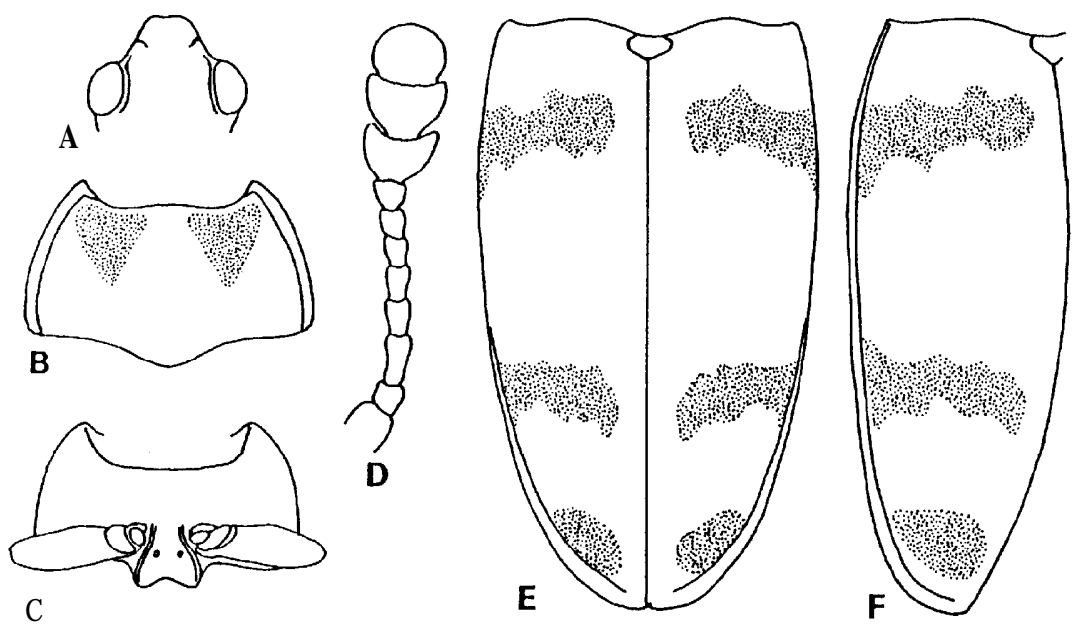

Fig. 7. Episcaphula (Tropidoscaphula) sedlaceki sp. nov. A : Dorsal view of head. B : Dorsal view of pronotum. C : Ventral view of prosternum. D : Dorsal view of left antenna. E : Dorsal view of elytra. F : Dorso-lateral view of left elytron. 
Pronotum transverse $(3: 5)$, trapezoidal, gently convex, sparsely aciculate, subbasal area strongly punctate at both sides, with a pair of obtriangular markings behind apical margin ; median $2 / 5$ of basal border roundly expanded, hind corner rather angulate ; lateral border gently arcuate, gradually converging forwards, comparatively widely marginate and reflexed, with a large and deep puncture near both extremities ; apical corner triangularly projected forwards, front border nearly straight, Prosternum convex at median part, with irregular fine wrinkles, sparsely pubescent-punctate ; prosternal process widened apically, lateral border weakly arcuate, apical border shallowly sinuate, procoxal lines long. Scutellum rather pentagonal, with rounded sides and angles, very sparsely aciculate.

Elytra as wide at base as pronotum, widened to $1 / 4$ from base, and then gradually tapered posteriorly, front corner comparatively widely rounded, lateral border rather widely marginate and reflexed, dorsum rather strongly convex, with somewhat vestigial nine files of punctures, interstices sparsely aciculate, each elytron with two narrow fasciae at about $1 / 4$ and $3 / 5$ from base, and one marking at subapical part, subbasal one waving and weakly slanted down outwards, its interior side widely separated from suture and exterior side reaching just inside of marginal area, post median fascia conversely slanted down inwards, its interior side not reaching 1 st interstices, exterior side hardly reaching marginal area, subapical one somewhat circular or oblique-oval, slightly aparted from suture and margin.

Mesosternum transverse, feebly convex, with ( )-shaped grooves at median part, mesepisternum and mesepimeron smooth. Metasternum strongly convex, sparsely pubescent-punctate, with very fine median line throughout median part; metepisternum and metepimeron nearly smooth. Abdominal sternites wholly and densely pubescent-punctate.

Length :8.5-10.0 mm. Width : 3.8-4.9 mm.

Type material : Holotype ơ (preserved in B. P. Bishop Mus.), Woitape (1,550-1,750 m), N. G . (SE), 2-3. xi. 1965, J. \& M. Sedlacek. Paratypes :, , Wau Ck. (1,200-1,500 m), Wau, Morobe Distr., P .

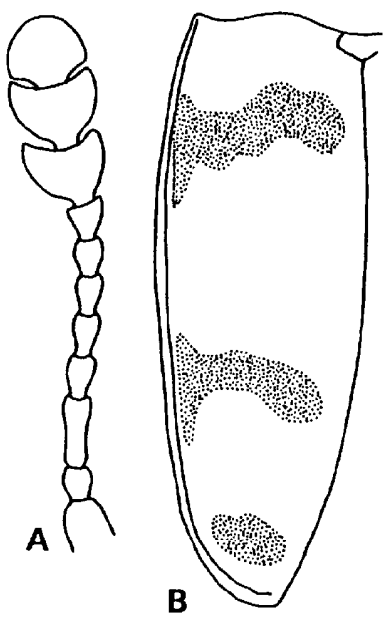

Fig. 8. Episcaphula (Tropidoscaphula) sedlaceki mayolana subsp. nov. A : Dorsal view of right antenna. B : Dorso-lateral view of left elytron. 
N. G. (NE), 28. iii. 1963, J. Sedlacek ; $9,24-26$ km SE. Okapa (1,800-1,900 m), P. N. G. (NE), 25. viii. 1964, M. Sedlacek ;20 $\sigma^{\top} \&$ , Arabuka (1,500-2,000 m), Morobe Distr., P. N. G. (NE), 7. i. 1968, J. \& M. Sedlacek ; ণ̛', Wau (1,200-1,600 m), Morobe Distr., P. N. G. (NE), 9. ii. 1968, J. \& M. Sedlacek.

Gen. distr. : Papua New Guinea (Morobe Distr.).

This species is related to E.(T.) stresemanni Heller, 19'20 from Ceram Island, but is easily distinguished from the latter by the following characters : Body much smaller, head evenly black, largely and sparsely punctate, pronotum with two obtriangular markings at a little behind anterior border, two fasciae and one marking on elytron, the fasciae and marking not making C-form but independently situated each other, prosternum somewhat widely and roundly convex at median part, with many transversal wrinkles, all legs black to blackish brown.

\section{Episcaphula (Tropidoscaphula) sedlaceki mayolana subsp. nov.}

This subspecies is closely related to nominate subspecies of E.(T.) sedlaceki sp. nov., but is separated from the latter by the following characters : Wholly blackish, with pubescent-punctures on whole surface much larger and denser, relative length of each antennal segment (base to apex) 4.0 : $2.0: 4.0: 2.5: 2.5: 2.5: 2.2: 2.0: 4.0: 4.5: 4.0$, five files of punctures recognized only in post median fascia, subbasal and post median fasciae yellow, all legs blackish.

Length : $9.4 \mathrm{~mm}$. Width : $4.1 \mathrm{~mm}$.

Type material : Holotype ơ (preserved in B. P. Bishop Mus.), Mayola II, P. N. G. (NE), 2. xi. 1984. M. T. Châjô.

Gen. DISTR. : Papua New Guinea (Mayola).

\section{Episcaphula (Tropidoscaphula) sedlaceki nigripes subsp. nov.}

This subspecies closely related to $E$. (T.) sedlaceki sedlaceki subsp. nov. and $E$.(T.) sedlaceki mayolana subsp. nov., but is easily distinguished from the latters by the following characters : General color paler, punctures on whole surface much stronger, relative length of each antennal segment (base
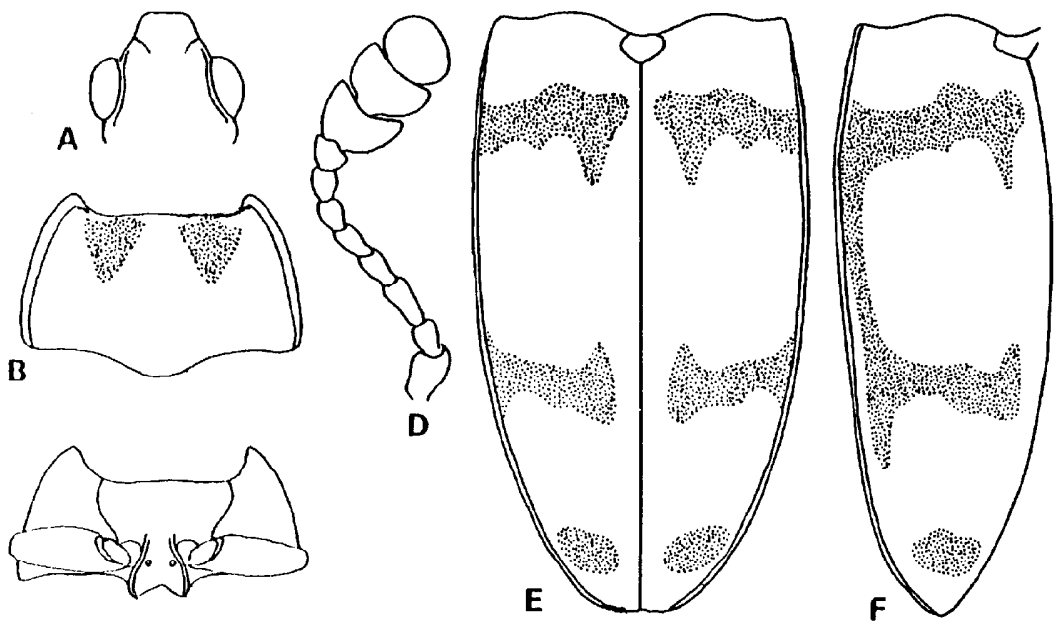

Fig. 9. Episcaphula (Tropidoscaphula) sedlaceki nigripes subsp. nov. A : Dorsal view of head. B : Dorsal view of pronotum. C : Ventral view of prosternum. D : Dorsal view of left antenna. E : Dorsal view of elytra. F : Dorso-lateral view of left elytron. 
to apex) $4.0: 2.0: 4.0: 3.0: 2.8: 2.5: 2.5: 2.5: 5.0: 5.0: 5.0$, elytral fasciae nearly transverse, interior end of subbasal fascia with narrow projection towards apex, interior end of post median fascia with narrow projection towards base, exterior ends of both fasciae linked with narrow and same colored longitudinal stria along lateral marginal area. Legs wholly dark brown.

Length : 8.8-9.6 mm. Width : 3.8-4.3 mm.

Type Material : Holotype ơ (preserved in B. P. Bishop Mus.), 8 km W. Mendis (2,150 m), N. G. (SE), 5-12. xii. 1967, P. Colman. Paratopotype : Q, same collecting data as holotype. Paratype : ơ (malaise trap), Tomba (2,450 m), Slopes of Mt. Hagen, P. N. G. (NE), 25. v. 1963, J. Sedlacek.

Gen. DISTR. : Papua New Guinea (Highlands).

\section{Episcaphula (Tropidoscaphula) quadrisignata Crotch}

Episcaphula quadrisignata Crotch, 1876, Cist. Ent., 1(13) : 410 (Batchian). - Gemminger et Harold, 1876, Cat. Col. Syn. Syst., 12 :3684. - Kuhnt, 1909, Wytsman's Gen. Ins., (88) : 112 ;1911., Junk’s Col. Cat., (34) : 79. - Heller, 1918 (1920), Arch. f. Naturg., 84, A(8) : 111 (key) (as Tropidoscaphula subgen. nov.).

Spec. exam. : 1 ex., Kiunga, Fly River, P. N. G. (NE), 24-27. viii. 1957, W. W. Brandt.

Length: $8.9 \mathrm{~mm}$. Width: $4.4 \mathrm{~mm}$.

Gen. DISTR. :Bacan I. \& Papua New Guinea.

Note : This species is newly recorded from the mainland of Papua New Guinea.

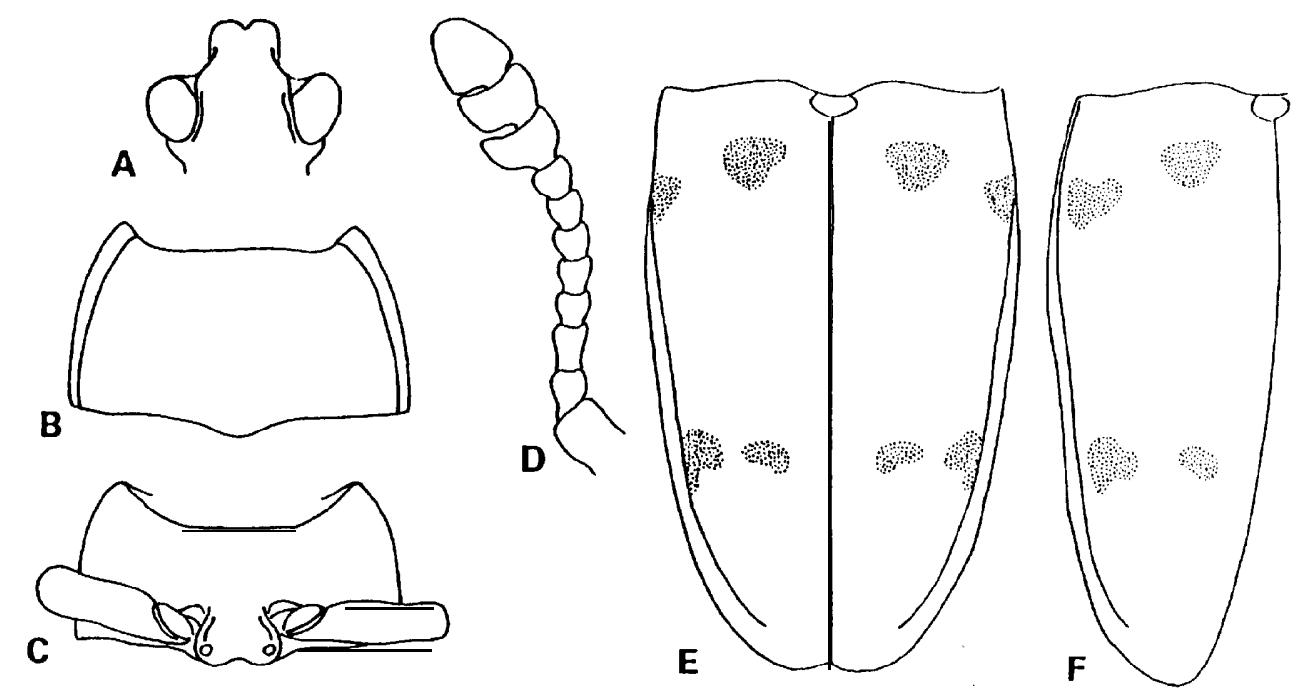

Fig. 10. Episcaphula (Tropidoscaphula) quadrisignata Crotch. A : Dorsal view of head. B : Dorsal view of pronotum. C : Ventral view of prosternum. D : Dorsal view of right antenna. E : Dorsal view of elytra. F: Dorso-lateral view of elytron. 